\title{
A Promoter Polymorphism of the Alpha 8 Integrin Gene and the Progression of Autosomal-Dominant Polycystic Kidney Disease
}

\author{
Raoul Zeltner $^{\mathrm{a}} \quad$ Karl F. Hilgers $^{\mathrm{a}}$ Roland E. Schmieder ${ }^{\mathrm{a}}$ Markus Porst $^{\mathrm{a}}$ \\ Bernd D. Schulze ${ }^{a}$ Andrea Hartner ${ }^{b}$ \\ ${ }^{\mathrm{a}}$ Department of Nephrology and Hypertension, and ${ }^{\mathrm{b}}$ Children and Youth Hospital, University of \\ Erlangen-Nuremberg, Erlangen, Germany
}

\section{Key Words}

Alpha 8 integrin · Promoter - Autosomal-dominant polycystic kidney disease $\cdot$ Association study $\cdot$ End-stage renal disease

\begin{abstract}
Background/Aims: Dysregulation of integrins is a feature of tissue remodeling in autosomal-dominant polycystic kidney disease (ADPKD). The alpha 8 beta 1 integrin $(\alpha 8 \beta 1)$ affects kidney development and the susceptibility to renal injury in mice. We investigated whether the $-414 \mathrm{~T} / \mathrm{C}$ polymorphism in the promoter region of the alpha 8 integrin chain gene (ITGA8) is associated with the progression of renal disease in ADPKD. Methods: Genotyping for the -414 T/C polymorphism was performed by allelic separation using RT-PCR in 294 patients with ADPKD. Alpha 8 integrin expression was detected by RT-PCR and immunohistochemistry. Results: $41 \%$ of the study population reached end stage renal disease at a mean age of $51 \pm 12$ years. The frequency of the $-414 \mathrm{C}$ allele was 0.194 in ADPKD. C allele carriers (CC and TC genotypes) were compared with patients homozygous for the $T$ allele (TT genotype). Kaplan-Meier analysis revealed that end-stage renal failure occurred at a significantly younger age in TT homozygotes (median age, 47 years; $95 \% \mathrm{Cl}, 46-49$ years) than in $\mathrm{C}$ allele carriers (median age, 51 years; $95 \% \mathrm{Cl}$, $49-53$ years; $p=0.046$ by the log-rank test). When parameters of ADPKD patients were compared between genotype by analysis of variance, only age at onset of end-stage renal
\end{abstract}

\section{KARGER \\ Fax +41613061234 \\ E-Mail karger@karger.ch}

www.karger.com

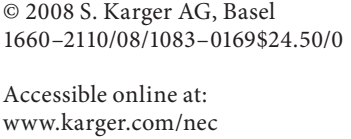

failure was significantly different $(p=0.026)$ whereas age at onset of hypertension, body surface area, 24-hour systolic and diastolic blood pressure did not differ. In kidneys of ADPKD, expression of alpha 8 integrin is increased and found de novo in cystic epithelia. Conclusion: A polymorphism of the ITGA8 promoter modifies the progression of renal failure in ADPKD.

Copyright $\odot 2008$ S. Karger AG, Basel

\section{Introduction}

The alpha 8 beta 1 integrin ( $\alpha 8 \beta 1)$ belongs to a family of heterodimeric cell-matrix receptors consisting of one $\alpha$ and one $\beta$ subunit $[1,2]$. Altered expression of $\beta 1$ integrins as well as their matrix ligands has been described in chronic kidney diseases, including several forms of glomerulonephritis [3,4], diabetic nephropathy [5] or acute renal failure [6]. Moreover, upregulation of $\beta 1$ integrins was shown in animal models of glomerular disease $[7,8]$. The role of integrins for the severity or progression of glomerular disease is still a matter of investigation and in some cases controversial: $\alpha 1 \beta 1$ integrin apparently exerted profibrotic effects in a model of glomerulonephritis in the rat [9], whereas lack of $\alpha 1 \beta 1$ led to severe glomerulosclerosis following glomerular injury induced by adriamycin [10]. The integrin chain $\alpha 8$ is expressed in mesenchymal and neuronal cells and heterodimerizes exclusively with the $\beta 1$ chain $[11,12]$. Integrin $\alpha 8 \beta 1$ is a 
receptor for fibronectin, vitronectin, tenascin C, osteopontin and nephronectin [13-15]. In the healthy kidney, expression of the $\alpha 8$ chain is restricted to glomerular mesangial cells and vascular smooth muscle cells [16]. An increase in $\alpha 8$ integrin expression was detected in models of glomerulonephritis [16] and glomerular hypertension [17]. In renal interstitial fibrosis, some activated myofibroblasts express $\alpha 8$ integrin de novo [17]. Studies of the sequelae of glomerular hypertension in these mice revealed a role for integrin $\alpha 8 \beta 1$ in maintaining the integrity of the glomerular capillary tuft during mechanical stress [17]. Lack of $\alpha 8 \beta 1$ leads to abnormalities of kidney development and to an increased susceptibility to renal injury in mice. Mice with a homozygous deletion of the $\alpha 8$ integrin chain have a reduced renal mass due to impaired epithelial-mesenchymal interactions in early stages of kidney development [18]. However, glomeruli and vessels are apparently normal with only subtle morphological alterations and no overt functional abnormalities [19].

Autosomal-dominant polycystic kidney disease (AD$\mathrm{PKD}$ ) is the most common hereditary renal disease, and frequently leads to end-stage renal disease (ESRD) [20]. In polycystic kidney diseases (including ADPKD), a dysregulation of several integrin chains was detected in tubular and cystic epithelial cells [21]. Colocalization of integrin $\alpha 2 \beta 1$ and polycystin- 1 , the protein most frequently affected in ADPKD, was described in focal adhesion complexes [20]. Moreover, it was shown that suppression of polycystin-1 was associated with an increase of $\alpha 2 \beta 1$ integrin and subsequently increased cell survival [22]. Accumulation of tenascin, a ligand for $\alpha 8 \beta 1$ integrin, was described in ADPKD [20]. Whether or not $\alpha 8 \beta 1$ integrin is involved in the pathogenensis and/or progression of ADPKD is completely unknown. However, $\alpha 8$ integrindeficient mice display increased expression of $\alpha 2 \beta 1$ integrin [19]. Moreover, both polycystin and $\alpha 8 \beta 1$ integrin seem to play a role for sprouting of the ureteric bud during early kidney development [20]. We tested whether a polymorphism in the promoter region of the integrin $\alpha 8$ chain gene (ITGA8) is associated with the progression of renal failure in ADPKD.

\section{Materials and Methods}

\section{Patients}

A cohort of 294 patients with autosomal polycystic kidney disease (ADPKD) from southern Germany was included in our study. Eighty percent of these patients were hypertensive. Data on the age at onset of ESRD, gender, body mass index and hyperten- sion status were collected from all patients. Data on 24-hour ambulatory systolic and diastolic pressure, and the age at diagnosis of hypertension was available for the majority of patients. The study protocol was approved by the local Ethics Committee (University of Erlangen-Nuremberg, Germany). All patients provided informed consent.

\section{Immunohistochemistry}

Frozen renal specimens were from kidney explants from 7 ESRD patients with ADPKD. Nephrectomies were performed because of the size of the kidneys in preparation for future kidney transplantations. Five control kidney specimens were taken from healthy parts of tumor explants. The use of anonymous pathologic material was approved by the local Ethics Committee (University of Erlangen-Nuremberg, Germany). For detection of $\alpha 8$ integrin, $2-\mu \mathrm{m}$ cryosections were prepared. Staining of cryostat sections was performed as described elsewhere [23]. In brief, sections were fixed with acetone for $10 \mathrm{~min}$. Unspecific staining was reduced by blocking with fetal calf serum for $10 \mathrm{~min}$, then the sections were layered with the primary anti- $\alpha 8$ integrin antibody (rabbit anti-mouse, cross-reacting with human) in a 1:50 dilution overnight at $4^{\circ} \mathrm{C}$. After washing with tris-buffered saline, sections were layered with CY3-labeled anti-rabbit IgG (DAKO Diagnostica, Hamburg, Germany) as secondary antibody for $1 \mathrm{~h}$ in the dark (1:400). Stained sections were embedded in mowiol and evaluated in a Leitz Aristoplan microscope (Leica Instruments).

\section{Real-Time PCR}

Renal tissue $(10 \mathrm{mg})$ from frozen kidney explants from 5 ESRD patients with ADPKD and 5 control kidney specimens from healthy parts of tumor explants was homogenized in $500 \mu \mathrm{l}$ of RLT buffer reagent (Quiagen, Hilden, Germany) with an ultraturrax for $30 \mathrm{~s}$, and total RNA was extracted with RNeasy Mini columns (Quiagen) according to the standard protocol. First-strand cDNA was synthesized with TaqMan reverse transcription reagents (Applied Biosystems, Darmstadt, Germany) using random hexamers as primers. Final RNA concentration in the reaction mixture was adjusted to $0.1 \mathrm{ng} / \mu \mathrm{l}$. Reactions without Multiscribe reverse transcriptase were used as negative controls for genomic DNA contamination. RT products were diluted $1: 1$ with $\mathrm{dH}_{2} \mathrm{O}$ before the PCR procedure. PCR was performed with an ABI PRISM 7000 Sequence Detector System and SYBR Green reagents (Applied Biosystems) according to the manufacturer's instructions.

For amplification of the mouse $\alpha 8$ integrin cDNA, the forward primer was 5'-TCA AGG CGA GGA ACA GCA A-3' and the reverse primer was $5^{\prime}$-CCT TGG GAA CCC GAT GGT-3'. The relative amount of the specific mRNA was normalized with respect to $18 \mathrm{~S}$ rRNA. Primers used for amplification of $18 \mathrm{~S}$ cDNA were: forward primer $5^{\prime}$-TTG ATT AAG TCC CTG CCC TTT GT-3' and reverse primer 5'-CGA TCC GAG GGC CTC ACT A-3'. All samples were run in triplicate.

\section{Allelic Separation of the -414 T/C Polymorphism by}

TaqMan PCR

The human gene for the $\alpha 8$ integrin chain (ITGA8) is localized on chromosome 10p13. PKD-1 is localized on 16p13 and PKD-2 on $4 \mathrm{q} 21$. Genotyping for the $-414 \mathrm{~T} / \mathrm{C}$ polymorphism was performed by allelic separation using RT-PCR in 294 patients with ADPKD. The following primers and probes were used: forward 


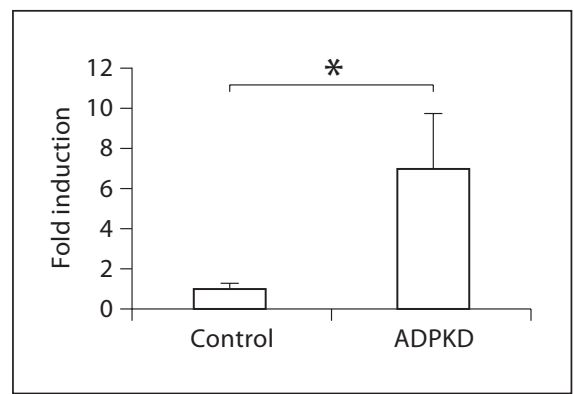

Fig. 1. Expression of mRNA for $\alpha 8$ integrin in ESRD kidney explants of ADPKD patients compared to control kidneys evaluated by RT-PCR. $n=5$ per group. Data are means \pm SEM. ${ }^{*} \mathrm{p}<0.05$ ADPKD vs. controls.

primer: GCGCTGGGTGCCTCTT, reverse primer: GGTGACAGAGACGAAACTGATTGT, reporter 1: ATTTCTATTGCAGTCCCATC-vic and reporter 2: CTATTGCGGTCCCATC-fam.

\section{Analysis of Data}

Presence of ESRD and age at onset were compared between genotypes by $\chi^{2}$ and Kaplan-Meier analysis. Blood pressure levels and age of onset of ESRD were compared by the two-tailed t test. $\mathrm{p}<0.05$ was considered significant. The procedures were carried out using the SPSS version 13.0 software (SPSS Inc., Chicago, Ill., USA). Values are displayed as means \pm SEM.

\section{Results}

An increase in $\alpha 8$ integrin expression was detected in the tissue of kidney explants from ESRD patients with ADPKD compared to control kidneys (fig. 1). The localization of $\alpha 8$ integrin was evaluated in sections of ADPKD explants and control kidney tissue. Similar to the findings in control renal tissue (fig. 2a), $\alpha 8$ integrin was detected in the vasculature and in the glomerular mesangium of cystic kidneys (fig. 2b, c). However, in ADPKD kidneys de novo expression of $\alpha 8$ integrin was detected in epithelial cells, mainly in cyst walls (fig. 2d-f).

Figure 3 shows allelic separation of the CC, TC and TT genotype. 186 ADPKD patients were of the TT genotype, 102 of the TC genotype and 6 of the CC genotype. The distribution of genotypes was consistent with the HardyWeinberg equilibrium. The frequency of the $-414 \mathrm{C}$ allele was 0.194 in ADPKD patients. Due to the very low number of CC homozygotes (6 of 294), C allele carriers (CC and TC genotypes) were compared with patients homozygous for the T allele (TT genotype).

$41 \%$ of the study population reached ESRD at a mean age of $51 \pm 12$ years. The number of patients on renal
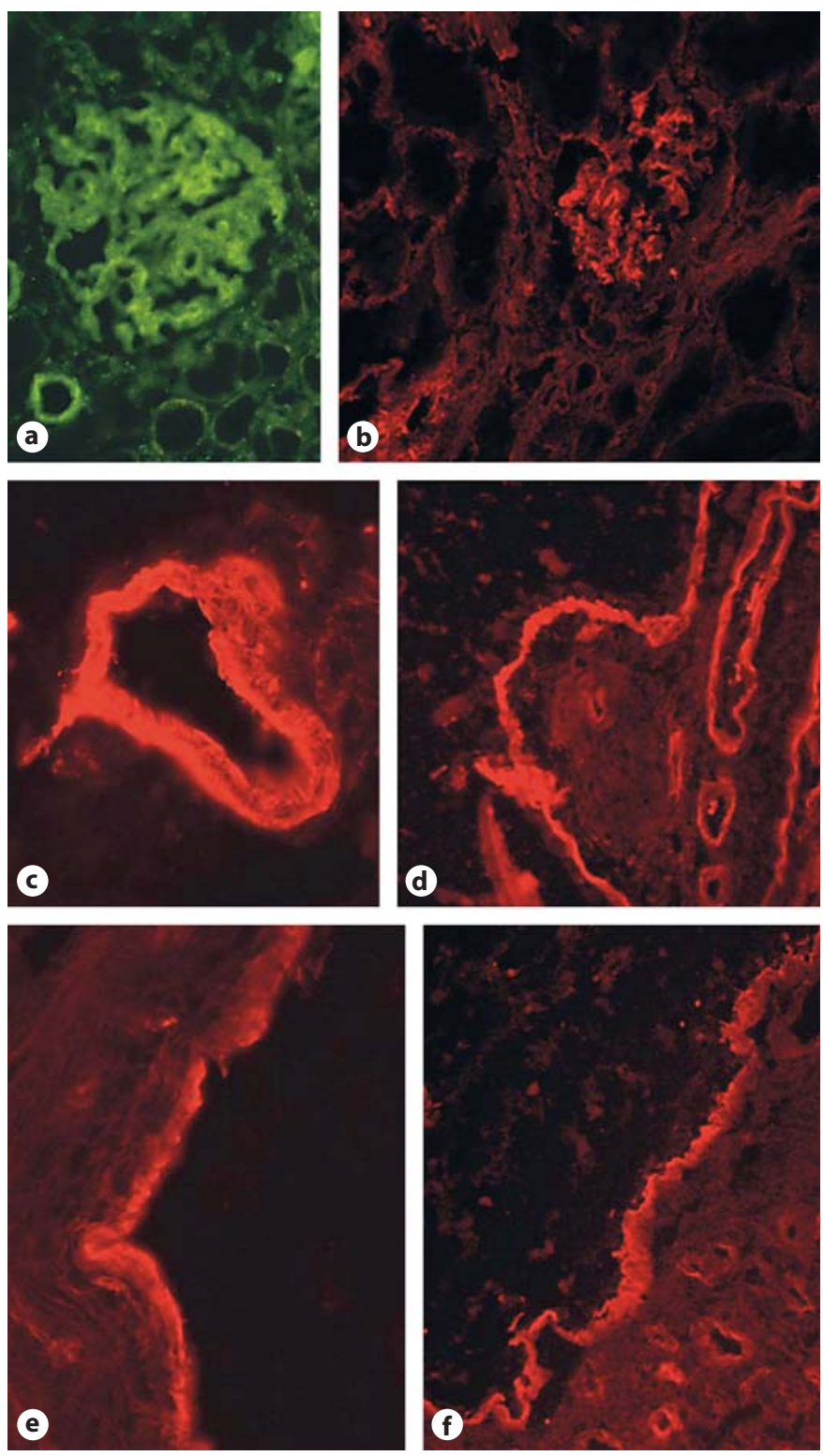

Fig. 2. Localization of $\alpha 8$ integrin in ESRD kidney explants of ADPKD patients by immunofluorescent staining of renal sections. a Control kidney. $\alpha 8$ integrin is localized to the mesangium of the glomerulus and to the media of the renal vasculature. b-f ADPKD kidney: $\alpha 8$ integrin is localized to glomeruli (b), renal arterial vasculature (c) and cyst walls (d-f).

replacement therapy was not affected by the ITGA8 genotype. However, C allele carriers needed renal replacement therapy at a significantly higher age: Kaplan-Meier analysis revealed that ESRD occurred earlier in TT homozygotes (median age, 47 years; 95\% CI, 46-49 years) than in $\mathrm{C}$ allele carriers (median age, 51 years; $95 \% \mathrm{CI}$, 


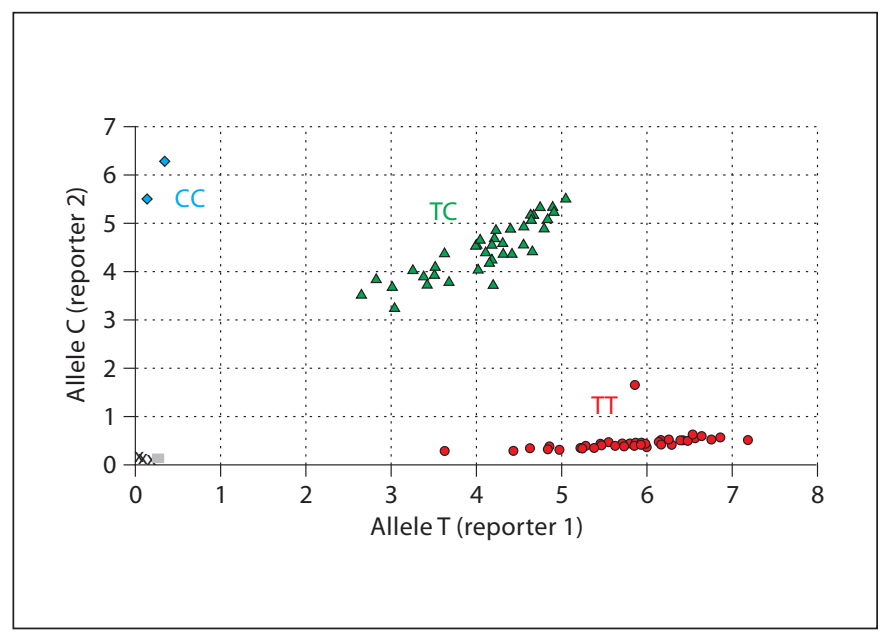

Fig. 3. Allelic separation by TaqMan RT-PCR analysis. Unanimous identification of the genotypes was achieved.

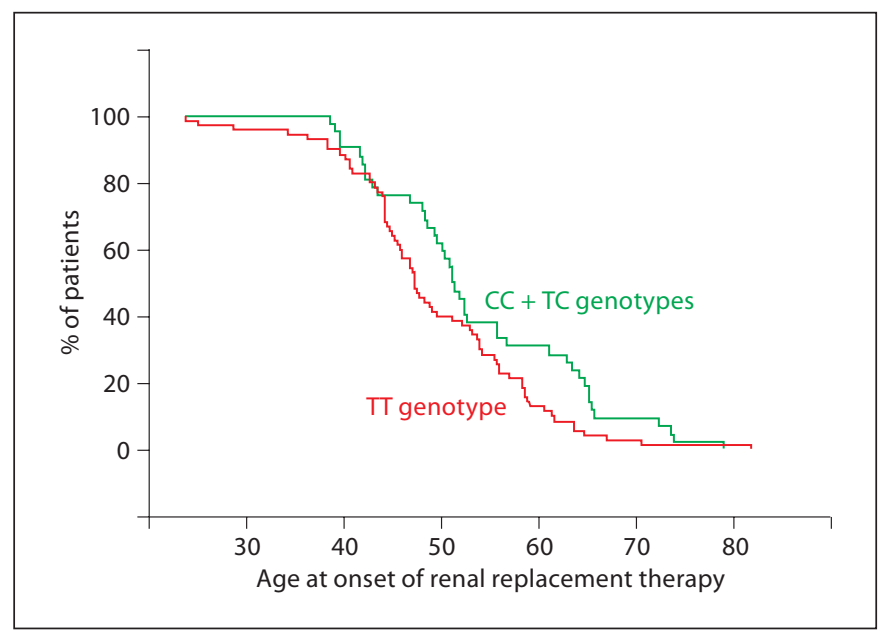

Fig. 4. Age at the onset of renal replacement therapy of the TT and CC/TC genotypes. Kaplan-Meier analysis reveals a significantly earlier onset of ESRD in individuals carrying the TT genotype.

Table 1. Data from all ADPKD patients

\begin{tabular}{lcccc}
\hline & TT & CC + TC & Test & p value \\
\hline Male:female & $100: 86$ & $54: 54$ & $\chi^{2}$ & 0.547 \\
Smoker:nonsmoker & $38: 111$ & $20: 65$ & $\chi^{2}$ & 0.756 \\
ESRD yes:no & $78: 108$ & $44: 64$ & $\chi^{2}$ & 0.902 \\
Age at onset of ESRD, years & $49 \pm 10$ & $54 \pm 11$ & $\mathrm{t}$ test & 0.026 \\
Age at hypertension diagnosis, years & $34 \pm 14$ & $36 \pm 13$ & $\mathrm{t}$ test & 0.171 \\
24-hour ambulatory systolic BP, mm Hg & $137 \pm 15$ & $137 \pm 16$ & $\mathrm{t}$ test & 0.838 \\
24-hour ambulatory diastolic BP, mm Hg & $85 \pm 10$ & $86 \pm 10$ & $\mathrm{t}$ test & 0.595 \\
\hline
\end{tabular}

Table 2. Data from ADPKD patients on renal replacement therapy

\begin{tabular}{lcccc}
\hline & TT & CC + TC & Test & p value \\
\hline Male:female & $48: 30$ & $28: 16$ & $\chi^{2}$ & 0.488 \\
Smoker:nonsmoker & $9: 41$ & $5: 21$ & $\chi^{2}$ & 0.563 \\
Age at onset of ESRD, years & $49 \pm 10$ & $54 \pm 11$ & t test & 0.026 \\
Age at hypertension diagnosis, years & $32 \pm 18$ & $35 \pm 13$ & t test & 0.349 \\
24-hour ambulatory systolic BP, mm Hg & $139 \pm 17$ & $141 \pm 19$ & t test & 0.620 \\
24-hour ambulatory diastolic BP, mm Hg & $84 \pm 11$ & $85 \pm 10$ & t test & 0.631 \\
\hline
\end{tabular}

49-53 years; $\mathrm{p}=0.0463$ by the log-rank test) as illustrated in figure 4 . When parameters of all ADPKD patients were compared between genotype by analysis of variance, only age at onset of ESRD was significantly different ( $\mathrm{p}=$ 0.026 ) whereas age at onset of hypertension, body weight, height, 24-hour systolic and diastolic blood pressure did not differ (table 1). The blood pressure data are of limited value, as they were obtained at different stages of renal failure and under different medications. A comparison of the collected data only from ADPKD patients on renal replacement therapy revealed no differences in the age at onset of hypertension, 24-hour systolic and diastolic blood pressure between the genotypes (table 2). 


\section{Discussion}

In the present study, we demonstrate that the $-414 \mathrm{~T} / \mathrm{C}$ polymorphism of the $\alpha 8$ integrin chain gene promoter is associated with the age at onset of ESRD in ADPKD. This promoter polymorphism is present in the European population in a distribution which is consistent with the Hardy-Weinberg equilibrium. As the $-414 \mathrm{~T} / \mathrm{C}$ polymorphism occurs at the binding site for the transcription factor common factor-1 [24], it is conceivable that binding of this transcription factor and subsequently the transcription of the $\alpha 8$ integrin chain gene could be affected by this polymorphism. Common factor-1 was described to serve as a transcriptional activator, e.g. of the c-myc gene or the skeletal $\alpha$-actin, and tends to be ubiquitously expressed in all tissues investigated [24]. However, there is at present no experimental evidence to support the notion that this promoter polymorphism reflects differences in $\alpha 8$ integrin expression levels. The small number of specimens from ADPKD kidneys which were available for RT-PCR analysis precluded a comparison of $\alpha 8$ integrin mRNA expression between genotypes.

Nevertheless, we detected an increase of $\alpha 8$ integrin mRNA expression and de novo $\alpha 8$ integrin protein expression in the walls of cysts from ADPKD kidney sections. Changes in $\alpha 8$ integrin expression have not been described in human kidney diseases before, although there is some evidence that expression of $\alpha 8$ integrin is altered in a rat model of hypertensive nephropathy [17] where it seems to contribute to maintaining the structural integrity of glomeruli. A dysregulation of other integrins was found in $\mathrm{AD}$ $\mathrm{PKD}$. An upregulation of the collagen receptor component $\alpha 1$ integrin chain was detected in normal and cystic collecting duct cells of ADPKD [21]. The distribution of integrin subunits $\alpha 2, \alpha 3$ and $\alpha 6$ was irregular in cyst walls [21]. Joly et al. [25] demonstrated increased integrin $\beta 4$ gene expression associated with increased expression of its ligand laminin-5 in ADPKD. Thus, it is conceivable that changes in integrin expression influence the development of renal cysts, possibly via altering cell-matrix interactions [20]. Upon activation, integrins colocalize with a number of focal adhesion proteins to form focal adhesions, which link cytoskeletal components in the cell to extracellular matrix outside the cell $[20,26]$. Polycystin-1, the protein most commonly affected in ADPKD, seemed to be localized to these focal adhesion complexes [20]. Moreover, another molecule present in focal adhesions, tensin, was shown to be of critical importance for preventing cyst formation [27]. Mice deficient for tensin develop renal cystic disease resembling human ADPKD.

$\alpha 8$ Integrin Promoter Polymorphism and ADPKD
Another feature of ADPKD is a change in the composition of matrix molecules, sometimes associated with interstitial fibrosis $[21,25,28]$. Particularly, a marked increase in tenascin deposition frequently accompanies ADPKD $[28,29]$. As tenascin is a ligand for $\alpha 8$ integrin [13] and as it is expressed in the subepithelial lining of cyst walls [28], which in turn are shown here to express $\alpha 8$ integrin, signaling events from the matrix via $\alpha 8$ integrin might influence cellular functions of cystic epithelial cells. A typical feature of these cells is abnormal cell proliferation [30], which can also be detected in animal models of polycystic kidney disease [31]. A contribution of $\alpha 8$ integrin to the regulation of cell proliferation was described in mesangial cells [32]. Expression of $\alpha 8$ integrin was associated with a decrease of cell proliferation. Thus, the de novo expression of $\alpha 8$ integrin in cystic epithelia might be considered as an attempt to reduce pathologic cell growth in ADPKD. On the other hand, expression of $\alpha 8$ integrin in vascular smooth muscle cells proved to be important for the maintenance of the mesenchymal phenotype of the cells [33]. Expression of $\alpha 8$ integrin might indicate that epithelialiszation of cyst walls is reduced, a notion which is supported by the finding that in the cyst epithelia of ADPKD kidneys alterations in cell polarity were found [34]. Membrane polarization is essential for the maturation of renal epithelia. A mispolarization [35] or underexpression [36] of E-cadherin detected in cyst walls could also be a characteristic of a mild dedifferentiation in cyst epithelia.

Alternatively, $\alpha 8$ integrin might be involved in the development of fibrotic changes in ADPKD, as suggested by Levine et al. [37] and Bouzeghrane et al. [38] for pulmonary, hepatic and myocardial fibrosis, respectively. We cannot rule out this possibility but consider it unlikely for two reasons. First, in our ADPKD kidney sections, $\alpha 8$ integrin immunoreactivity was primarily localized in cyst walls, not in the areas of fibrosis which were abundantly present in these end-stage kidneys. Second, our previous experiments in $\alpha 8$ integrin-deficient mice [17] did not support the notion that this integrin promotes fibrosis in the kidney. The lack of this integrin aggravated the hypertension-induced glomerular damage [17]. An increased susceptibility to hypertensive kidney injury could also contribute to the effect of the $\alpha 8$ integrin gene promoter polymorphism on the course of ADPKD. Association studies have investigated the potential role of genes involved in the regulation of blood pressure and hypertensive target organ damage, including endothelial nitric oxide synthase $[39,40]$ and angiotensin-converting enzyme [41, 42], as modifier genes for ADPKD. These 
studies, however, yielded conflicting results as to the importance of these genes for the time course of renal failure.

Several limitations of our study must be considered. First, the association design does not permit to establish a cause-and-effect relationship. Second, there are no data to prove that the $-414 \mathrm{~T} / \mathrm{C}$ promoter polymorphism affects the transcription of the gene, and we cannot exclude the possibility that the apparent effect of the polymorphism may be due to other polymorphisms in linkage disequilibrium with $-414 \mathrm{~T} / \mathrm{C}$. Third, the number of patients with ESRD was not large for an association study. Previously published association studies in ADPKD patients [39, 40,42], however, described cohorts of similar size. Finally, we did not genotype subjects for the PKD1 or PKD2 mutations, and we are therefore unable to exclude an interaction between the $\alpha 8$ integrin promoter polymorphism and the $P K D$ genotype.
Despite these limitations, our results point to the role of cell-matrix interactions for the development of cystic kidney diseases, especially in ADPKD. A dysregulation of molecules involved in the regulation of cell-matrix interactions may therefore contribute to renal tissue remodeling preceding cyst formation. Our data raise the hypothesis that the $\alpha 8$ integrin chain plays a role in this process.

\section{Acknowledgments}

This study was supported by a grant from the Deutsche Forschungsgemeinschaft, Bonn, Germany (SFB 423, Project A2). The authors thank Dr. Ulrich Muller (Scripps Institute, La Jolla, Calif., USA) for providing the antibodies to $\alpha 8$ integrin.

\section{References}

1 Giancotti FG: Complexity and specificity of integrin signalling. Nat Cell Biol 2000;2: E13-E14.

2 Giancotti FG, Ruoslahti E: Integrin signaling. Science 1999;285:1028-1032.

3 Kanahara K, Yorioka N, Arita M, Ohira N, Yamakido M: Immunohistochemical studies of extracellular matrix components and integrins in IgA nephropathy. Nephron 1994;66:29-37.

4 Kuhara T, Kagami S, Kuroda Y: Expression of beta 1-integrins on activated mesangial cells in human glomerulonephritis. J Am Soc Nephrol 1997;8:1679-1687.

5 Jin DK, Fish AJ, Wayner EA, et al: Distribution of integrin subunits in human diabetic kidneys. J Am Soc Nephrol 1996;7:26362645.

6 Goligorsky MS, Lieberthal W, Racusen L, Simon EE: Integrin receptors in renal tubular epithelium: new insights into pathophysiology of acute renal failure. Am J Physiol 1993; 264:F1-F8.

7 Kagami S, Border WA, Ruoslahti E, Noble NA: Coordinated expression of beta 1 integrins and transforming growth factor-betainduced matrix proteins in glomerulonephritis. Lab Invest 1993;69:68-76.

8 Kagami S, Kondo S: Beta1-integrins and glomerular injury. J Med Invest 2004;51:1-13.

9 Kagami S, Urushihara M, Kondo S, et al: Effects of anti-alphal integrin subunit antibody on anti-Thy-1 glomerulonephritis. Lab Invest 2002;82:1219-1227.
10 Chen X, Moeckel G, Morrow JD, et al: Lack of integrin alphalbetal leads to severe glomerulosclerosis after glomerular injury. Am J Pathol 2004;165:617-630.

11 Varnum-Finney B, Venstrom K, et al: The integrin receptor alpha 8 beta 1 mediates interactions of embryonic chick motor and sensory neurons with tenascin-C. Neuron 1995; $14: 1213-1222$

12 Schnapp LM, Breuss JM, Ramos DM, Sheppard D, Pytela R: Sequence and tissue distribution of the human integrin alpha 8 subunit: a beta 1-associated alpha subunit expressed in smooth muscle cells. J Cell Sci 1995; 108:537-544.

13 Schnapp LM, Hatch N, Ramos DM, Klimanskaya IV, Sheppard D, Pytela R: The human integrin alpha 8 beta 1 functions as a receptor for tenascin, fibronectin, and vitronectin. J Biol Chem 1995;270:23196-23202.

14 Denda S, Reichardt LF, Müller U: Identification of osteopontin as a novel ligand for the integrin alpha8 betal and potential roles for this integrin-ligand interaction in kidney morphogenesis. Mol Biol Cell 1998;9:14251435.

15 Brandenberger R, Schmidt A, Linton J, et al: Identification and characterization of a novel extracellular matrix protein nephronectin that is associated with integrin alpha8beta 1 in the embryonic kidney. J Cell Biol 2001; 154:447-458.

16 Hartner A, Schöcklmann H, Pröls F, Müller U, Sterzel RB: Alpha8 integrin in glomerular mesangial cells and in experimental glomerulonephritis. Kidney Int 1999;56:14681480 .
17 Hartner A, Cordasic N, Klanke B, Müller U, Sterzel RB, Hilgers KF: The alpha8 integrin chain affords mechanical stability to the glomerular capillary tuft in hypertensive glomerular disease. Am J Pathol 2002;160:861867.

18 Muller U, Wang D, Denda S, Meneses JJ, Pedersen RA, Reichardt LF: Integrin alpha8 beta1 is critically important for epithelialmesenchymal interactions during kidney morphogenesis. Cell 1997;88:603-613.

19 Haas CS, Amann K, Schittny J, Blaser B, Muller U, Hartner A: Glomerular and renal vascular structural changes in alpha8 integrin-deficient mice. J Am Soc Nephrol 2003; 14:2288-2296.

20 Wilson PD, Burrow CR: Cystic diseases of the kidney: Role of adhesion molecules in normal and abnormal tubulogenesis. Exp Nephrol 1999;7:114-124.

21 Daikha-Dahmane F, Narcy F, Dommergues M, Lacoste M, Beziau A, Gubler MC: Distribution of alpha-integrin subunits in fetal polycystic kidney diseases. Pediatr Nephrol 1997;11:267-273.

22 Battini L, Fedorova E, Macip S, Li X, Wilson PD, Gusella GL: Stable knockdown of polycystin-1 confers integrin-alpha2beta1-mediated anoikis resistance. J Am Soc Nephrol 2006;17:3049-3058.

23 Hartner A, Hilgers KF, Bitzer M, Veelken R, Schocklmann HO: Dynamic expression patterns of transforming growth factor-beta(2) and transforming growth factor-beta receptors in experimental glomerulonephritis. J Mol Med 2003;81:32-42. 
24 Riggs KJ, Merrell KT, Wilson G, Calame K: Common factor 1 is a transcriptional activator which binds in the c-myc promoter, the skeletal alpha-actin promoter, and the immunoglobulin heavy-chain enhancer. Mol Cell Biol 1991;11:1765-1769.

25 Joly D, Morel V, Hummel A, Ruello A, Nusbaum P, Patey N, et al: Beta4 integrin and laminin 5 are aberrantly expressed in polycystic kidney disease: role in increased cell adhesion and migration. Am J Pathol 2003. 163:1791-1800.

26 Craig SW, Johnson RP: Assembly of focal adhesions: progress, paradigms, and portents. Curr Opin Cell Biol 1996;8:74-85.

27 LoSH, Yu QC, Degenstein L, Chen LB, Fuchs E: Progressive kidney degeneration in mice lacking tensin. J Cell Biol 1997;136:13491361.

28 Klingel R, Ramadori G, Schuppan D, Knittel T, Meyer zum Buschenfelde KH, Kohler H: Coexpression of extracellular matrix glycoproteins undulin and tenascin in human autosomal dominant polycystic kidney disease. Nephron 1993;65:111-118.

29 Daikha-Dahmane F, Dommergues M, Narcy F, Lacoste M, Gubler MC: Distribution and ontogenesis of tenascin in normal and cystic human fetal kidneys. Lab Invest 1995;73: 547-557.
30 Nadasdy T, Laszik Z, Lajoie G, Blick KE, Wheeler DE, Silva FG: Proliferative activity of cyst epithelium in human renal cystic diseases. J Am Soc Nephrol 1995;5:1462-1468.

31 Ramasubbu K, Gretz N, Bachmann S: In creased epithelial cell proliferation and $\mathrm{ab}$ normal extracellular matrix in rat polycystic kidney disease. J Am Soc Nephrol 1998;9: 937-945.

32 Bieritz B, Spessotto P, Colombatti A, Jahn A, Prols F, Hartner A: Role of alpha8 integrin in mesangial cell adhesion, migration, and proliferation. Kidney Int 2003;64:119-127.

33 Zargham R, Thibault G: Alpha 8 integrin expression is required for maintenance of the smooth muscle cell differentiated phenotype. Cardiovasc Res 2006;71:170-178.

34 Avner ED, Sweeney WE Jr, Nelson WJ: Abnormal sodium pump distribution during renal tubulogenesis in congenital murine polycystic kidney disease. Proc Natl Acad Sci USA 1992;89:7447-7451.

35 Du J, Wilson PD: Abnormal polarization of EGF receptors and autocrine stimulation of cyst epithelial growth in human ADPKD. Am J Physiol 1995;269:C487-C495.

36 Rocco MV, Neilson EG, Hoyer JR, Ziyadeh FN: Attenuated expression of epithelial cell adhesion molecules in murine polycystic kidney disease. Am J Physiol 1992;262:F679F686.

37 Levine D, Rockey DC, Milner TA, Breuss JM, Fallon JT, Schnapp LM: Expression of the integrin alpha8betal during pulmonary and hepatic fibrosis. Am J Pathol 2000;156:19271935.
38 Bouzeghrane F, Mercure C, Reudelhuber TL, Thibault G: Alpha8beta1 integrin is upregulated in myofibroblasts of fibrotic and scarring myocardium. J Mol Cell Cardiol 2004; 36:343-353.

39 Lamnissou K, Zirogiannis P, Trygonis S, et al: Evidence for association of endothelial cell nitric oxide synthase gene polymorphism with earlier progression to end-stage renal disease in a cohort of Hellens from Greece and Cyprus. Genet Test 2004;8:319324.

40 Persu A, Stoenoiu MS, Messiaen T, et al: Modifier effect of ENOS in autosomal dominant polycystic kidney disease. Hum Mol Genet 2002;11:229-241.

41 Ecder T, McFann KK, Raynolds MV, Schrier RW: No effect of angiotensin-converting enzyme gene polymorphism on disease progression and left ventricular hypertrophy in autosomal dominant polycystic kidney disease. Am J Nephrol 2003;23:466-470.

42 Persu A, El-Khattabi O, Messiaen T, Pirson Y, Chauveau D, Devuyst O: Influence of ACE (I/D) and G460W polymorphism of alphaadducin in autosomal dominant polycystic kidney disease. Nephrol Dial Transplant 2003;18:2032-2038. 